\title{
Mesleki Öz Bilgi Olarak Tasarım Düşüncesi
}

\author{
Doç. Dr. Serkan Güneş \\ Çiğdem Güneş
}

Makale Geliș Tarihi: 05.05.2017

Yayına Kabul Tarihi: 15.05.2017

\section{Özet}

Meslekler bir birbirine bağımlı bir sistem oluşturur. Bu sistem içinde meslekler arası çatışmalar daha ziyade yetki çerçevesi dâhilinde oluşur. Yetki alanlarının belirsizliği hem icrada güçlük hem de diğer mesleklerin o alana müdahalesini mümkün kılar. Bu nedenle, her meslek alanı, yetki alanının sınırlarını belirleyecek kendine has özel bilgi kümesini oluşturmalıdır.

Bu çalışma endüstriyel tasarım mesleğinin temel bilgi kümesine yoğunlaşmaktadır. Bu amaç dâhilinde, çalışma, öncelikle meslek sosyolojisi hakkında bilgi verecek, mesleki bilginin mesleki farklılaşma üzerindeki etkisi irdelenecektir. Illerleyen bölümlerde, endüstriyel tasarım mesleğine ait öz bilgi olan tasarım düşüncesi üzerindeki mesleki tekel tartışmaları, profesyonelleşme tezleri üzerinden değerlendirilecektir. Çalışmanın son bölümünde tasarım düşüncesi üzerindeki tekel olma stratejileri tartışılacaktır.

Anahtar Sözcükler: Endüstriyel Tasarım, Tasarım Düşüncesi, Profesyonelleşme, Temel Bilgi Kümesi

\section{DESIGN THINKING AS A SUI GENERIS PROFESSIONAL KNOWLEDGE}

\begin{abstract}
Professions constitute an interdependent system. In general terms, in this system, struggles between the professions occur over their jurisdictions. The ambiguity of the jurisdictions makes it possible both difficulties in practice and intervention of other professions. For this reason, each profession must establish its own body of knowledge that will determine the boundaries of its jurisdiction.
\end{abstract}

This work focuses on the body of knowledge of the industrial design profession. Within this aim, the study will first give information about the sociology of the professions and examine the effect of the professional knowledge on the professional differentiation. In the following sections, as a sui generis knowledge of industrial design profession; the design thinking and monopoly over design thinking will be evaluated through professionalism theses. In the last part of the study, the strategies of monopoly over design thinking will be discussed.

Keywords: Industrial Design, Design Thinking, Professionalization, Body of Knowledge 


\section{Giriş}

Bu çalışmada endüstriyel tasarım alanını meslek kavramı üzerinden ele alacağız. Bu cüretkâr kapsamı kısıtlamak amacıyla çalışmamız daha ziyade endüstriyel tasarım alanının alana sahip özel temel bilgi kümesine yoğunlaşacaktır. Zira meslekler, bilimsel bilgiye dayalı olarak kabul ettikleri bilgi ile bağlantılı olarak tanımlanır; başka bir deyişle, kendilerine has bilginin aracıları ve uygulayıcılarıdırlar (Brante, 2011). Bir meslek alanının sahip olduğu bilginin ne olduğunu tanımlamadan önce meslek sosyolojisi açısından meslek, uğraş ve iş (zanaat) kavramaları arasındaki farkları belirlemek zorunludur. Bu nedenle çalışmamızın ilk bölümünde meslek kavramına farklı bakış açılarını tartışmamıza temel teşkil etmesi amacıyla üç sosyolojik yaklaşım üzerinden değerlendireceğiz. Daha sonra meslek, uğraş ve iş (zanaat) kavramaları arasındaki farkları literatür üzerinden tanımlamaya çalışacağız.

Meslek sosyolojisine dönük yaklaşımlarda ki farklar ise büyük oranda Anglosakson (Amerika ve İngiltere) ve Kita Avrupa'ya (Fransa ve Almanya) ait ekollerin sosyal yapılarındaki kültürel farklıklar ve devletin etki seviyesi nedeniyle meseleyi farklı ele alıs biçiminden kaynaklanır. Zira mesleklerin meşruiyeti açısından devletin rolü hep belirleyici olmuştur (Evetts, 2013). Günümüzde pazarın küreselleşmesi, meslek erbabının usul devlet sınıflarını aşan hareketliliğine rağmen İngiltere ve özellikle Amerika'da profesyonel meslekler yasaları etkileyen ve şekillendiren bir güce ve kendi alanlarında özerklik için devlet ile işbirliği kimi zaman rekabet edebilme imkânına sahip olmuştur. Bürokratik devletin gücünün daha fazla olduğu Fransa ve Almanya gibi kıta Avrupası ülkelerinde mesleki gruplar, devletin belirleyiciliği nedeniyle gücü ele geçirme ve profesyonelleşme yolunda bu imkânlardan mahrum kalmıştır (Gispen, 1989). Meslek sosyolojisinde ise bu tesirler altında ana üç yaklaşım göze çarpmaktadır (Ritzer, 1975). Bunlardan ilki olan yapısalcı yaklaşımda mesleklerin diğer mesleklerde olmayan statik karakteristikleri tarihsel olmayan bir bağlamda ele alınır. Greenwood (1957) ve Goode'nin (1957) meslekleri tanımlamaya yönelik çalışmaları yapısalcı yaklaşıma örnektir. Zira Greenwood'a (1957) göre tüm meslekler sistematik teori, otorite, toplumsal onay, etik kodlar ve kültür sıfatlarından oluşur. Süreçyaklaşımında ise bir uğraşın mesleğe dönüşmesindeki aşamalar tarihsel bir bağlamda ele alınır. Ritzer'e (1975) göre süreç yaklaşımı yapısalcı yaklaşım ile birleştirilerek uğraştan mesleğe doğru tarihsel ve sürekli bir uzanım geliştirilerek statik karakteristikler vasıtasıyla uzanımın uç noktalarına uğraş ve meslekleri konumlandırmak mümkün olmaktadır. Daha ziyade Freidson'un (1970) çalışmalarında yer alan güç yaklaşımı ise mesleklerin ana karakterini diğer meslekler üzerindeki tekel olma çabası 
olarak tanımlar. Freidson'a göre meslekler güç sahibi kurumlar haline gelmesi için toplumu ve diğer meslekleri ikna etmek zorunda kalmaktadır. Elbette bu ikna süreci sancılı olmakta, ileride değineceğimiz üzere meslekler arasındaki çatışmalara zemin hazırlamaktadır. Üç yaklaşımdan farklı olarak Marksist temelli yaklaşımlar güç kavramını merkeze alarak eleştirilerde bulunmaktadır. Bu eleştiriler güç sahibi meslekleri Durkheim ve Parsons gibi kamu yararına çalışan aracı kurumlar değil aksine kapitalist sistem içinde kendi ve egemen sınıfın çıkarlarına hizmet eden salt birer "proleter" olarak görmektedir.

Meslek, uğraş ve iş (zanaat) kavramaları çoğu zaman içerikleri tam olarak bilinmediğinden birbirleri yerine kullanılan kavramlardır. Süreç yaklaşımı açısından meslek kavramı diğerlerini kapsayan bir yapıdadır ve en üst seviyede profesyonel meslek aşamasına ulaşır. Bir meslek profesyonelleşme sürecinde bir uzanım üzerinde belirli özellikler kazanarak iş (zanaat), uğraş ve meslek aşamalarından geçer ${ }^{1}$. Bu çalışmanın kapsamı mesleklerin temel bilgi kümesi üzerine yoğunlaştığından iş (zanaat), uğraş ve meslek arasındaki farkı tanımlama amacıyla bu üç unsurun bilge ve beceri doğasını incelemek çalışmamızın amaçları açısından daha faydalı olacaktır. Bilgi ve becerinin doğası açısından iş'te (zanaat) temel bilgi ve beceri uğraşın dışındakilerce tutulmakta uğraşta ise bilgi ve beceri giderek ezoterik ${ }^{2}$ bir yapı sergilemeye başlamaktadır. Ancak uğraşın sahip olduğu bilgi ve becerilere uğraş dışındakiler kolayca ulaşabilmektedir. Meslek aşamasına gelindiğinde ise bilgi ve beceri ezoterik olup dışardan ulaşılması zorlaşmaktadır. Ulaşılma zorluğunun temel sebebi ise meslek alanının korunmasıdır. Dolayısıyla meslek olgusunun merkezinde bu alana has korunaklı özel bilgi bulunmaktadır (Kuhlmann, 2006). Meslek dışındaki bireyler bu özel bilgiye vakıf değildirler (Govier, 1997). Profesyonel meslek ise, en geniş anlamda, talep edilen kimi toplumsal ihtiyaçları gidermek amacıyla bu korunaklı özel bilginin mesleğin gerektirdiği özel yaşam tarzı ile harmanlanarak sunulmasına dayanan özel bir meslek alanı olarak tanımlanmaktadır (Svensson, 2006). Çalışmamızın takip eden bölümünde profesyonelleşme sürecinde mesleki bilgi kavramına değinilecektir.

\section{Mesleki Bilgi}

İnsan tarafından ihtiyaç duyulan envai çeşit faaliyetin, toplumsal işbölümü bağlamında bir grup tarafından kendine vazife olarak addedilmesi, bu

\footnotetext{
Yabancı literatürde meslek profession uğraş ise vocationveya occupation tanımları ile ifade edilmektedir. İs (zanaat) ifadesi ise daha ziyade craft ifadesine karşılık gelmektedir.

2 Ezoterik yapı, bir konudaki derin bilgilerin ve sırların ehil olmayanlardan gizlenerek, bir üstat tarafından sadece ehil olanlara inisiyasyon yoluyla öğretilmesidir. İnisiyasyon (Süluk) bir üstadın sert ve sürekli kontrolü altında, bir düzen ve disiplin içinde, sınavlara dayalı tarzda, metotlu olarak eğitimi şeklinde tanımlanmaktadır. Günümüzde inisiyasyonun yerini uzmanlaşmış lisans ya da lisansüstü eğitim ve bu eğitim sonucu almıştır.
} 
vazifelerin daha sonra organize bir mesleki icraya dönüşmesi karmaşık; daha da ötesi toplum seviyesinde izah gerektiren bir mekanizmadır. Fransız sosyolog Durkheim tarafından savunulan daha sonra Parsons tarafından geliştirilen işlevselci paradigmada toplum, uzun vadeli var olmanın temel işlevsel gereklerini kendikaynaklarındanalan birsistem olaraktanımlanmıştır (Parsons, 2005). Bu toplum yapısında birbirine kenetlenmiş ve evrim süreçlerine tanıklık eden parçalar bütün ile ilişki içindedir. Parçalar diğer parçalar ile uyum içinde ve yardımlaşmakta ve aynı zamanda toplumun bir bütün halinde çalışmasını sağlamaktadır. Toplumu oluşturan her bir toplumsal parça ve uygulama ancak toplumun yani bütünün ihtiyaçlarının karşılanmasında bir role sahip olması durumunda sürekliliğini korur. Diğer taraftan değişen koşullar karşısında toplumun kendisi topyekûn uyum göstermekte kimi zaman farklılaşarak işbirliği içinde yeni öğeler ve işlevler geliştirmektedir. Benzer şekilde Merton (1968) toplumda işlev boşluğunun olamayacağını belirtmiş, tatmin edilmeyen işlevin öyle ya da böyle; gayri meşru uygulamalar da dâhil olmak üzere, toplum tarafından doldurulacağını savunmuştur. Bu noktadan hareketle, işlevselci paradigma, meslekleri toplumsal bir talep sonucu ortaya çıkan, değişen koşullar altında evirilen, sürdürülebilirliği ancak toplumsal bir fayda yarattığı müddetçe devam eden bir öğe olarak görmüştür. Eğer toplumsal yapıda intiyaç duyulan mesleğin icrası için fonksiyonel yetersizlikleri var ise, toplumun öğeleri icraya dönük ihtiyaçların tatmini için alternatif yapılar üretmektedir. Bu alternatifler doğrudan kurumsal mesleki eğitimin tesisi kadar, sıradan bireylerin fayda maksimizasyonu motivasyonu altında o alandaki kurumsal veya icraya dönük boşluğu ve ayrıca rantı fark edip, kendisini o meslek erbabı olarak ilan etmesine kadar uzanmaktadır.

Bir mesleğin, toplumsal bir talep tarafından mı ortaya çıktığı, yoksa girişimci mesleklere olduğu üzere toplumda var olan örtük ihtiyacının kendilerine hatırlatılması sonucu mu tesis edildiği, kendi başına uzun bir tartışmadır. Çünkü bir mesleğin varlık gerekçesini bulmak için öncelikle ele alınması gereken konu mesleğin üzerine inşa edildiği daha sonrada onu diğerlerinden ayıran ve ona yaşam hakkı sunarak sürdürülebilirliğini sağlayan hususların ne olduğunu bulmaktır. Gorman ve Sandefur'a (2011) göre bir mesleği ortaya çıkaran dört adet nitelik vardır. Bu niteliklerden ilki ve ana meşruiyet kaynağı uzman bilgisidir. Uzman bilgisi meslek için hem sine qua non koşul hem de sui generistir. Uzman bilgisinin suigeneris olması o mesleğin diğer meslekler ile akrabalık kurmasına engel değildir. Aksineher uzman bilgisi bir bakıma diğer alanlardan o ihtiyaç için oluşturulan yeni bir harmandır. Mesleklerin üzerine inşa edildiği bu bilgiformal ve soyut prensiplere dayalı örtük ve deneyimsel bilgiden oluşur (Abbott, 1988) ve bu bilgi ile mesleki muayyen problemler çözülür (Gorman ve Sandefur, 2011). 
Young ve Muller'e (2014) göre ise bir mesleğin icrası için hem özelleşmiş bilgiye hem de pratiğe dayalı uzmanlığa ihtiyaç vardır. Birçok görüşe göre intiyaç duyulan özelleşmiş bilgi üniversitelerde verilmekte, uzmanlaşma ise mesleki icra ile oluşmaktadır. Bilgi profesyonellerin uzman olabilmek için elde etmeleri gereken şeydir (Young ve Muller, 2014). Morris ve Empson'a (1998) göre bilgi, iş erbabının deneyim ve mesleki eğitimine dayalı malumatından oluşur ${ }^{3}$. Abbott (1991) kurumsallaşmış mesleklerde mesleki bilginin deposu olarak meslek örgütlerini görmekte, Parsons (1954) ise bu bilginin niteliğini genel kaideler halinde kodlanmış tekno-rasyonel taban olarak tanımlamaktadır. Resmi olarak akredite olmayan mesleki bilgiye sahip mesleklerde ise mesleki bilgi firma ve birey ölçeğinde tutulmakta, fikri sınai haklara konu olmakta ve icap eden durumlarda dışarıya transfer edilmektedir (Morris ve Empson, 1998). Gelişmekte olan mesleklerde ise yaratılan bilgi ise daha kurumsallaşmamış ve genele yayılmamıştır. Yeni üretilen bu bilgi ham olduğu için gayrı resmi ve doğası gereği örtüktür (Polyani, 2009). Örtük bilginin tersi ise iyi belgelenmiş ve organize edilmiş genelleştirilebilen malumat sistemi oluşturur. Buna verilebilecek en iyi örneklerden birisi hukuki pratiktir. Örneğin bir avukattan en azından dava açmaya yeterli usulüne uygun ve rutin şekilde dava dilekçesi yazması beklenir.

Bilginin sınıflandırılması için önde gelen çalışmalardan birisi Collins (1993) tarafından yapılmıştır. Bu sınıflama daha sonra Blackler (1995) tarafından genişletilmiştir. Lam'a (2002) göre ise dört farklı bilgi tiplerinden bahsetmek mümkündür (Şekil 1).

\begin{tabular}{|c|c|c|c|}
\hline \multirow{2}{*}{$\begin{array}{c}\text { BILGININ } \\
\text { ODAĞI }\end{array}$} & Bireysel & $\begin{array}{c}\text { Uzmanlık / Alıştırma ile } \\
\text { pekiştirilen } \\
\text { (EMBRAINED) }\end{array}$ & $\begin{array}{c}\text { Deneyim / Bilgelik ve } \\
\text { Teknik olarak somutlaşan } \\
\text { (EMBODIED) }\end{array}$ \\
\hline & Toplu & $\begin{array}{l}\text { Örneklenerek, sistem ve } \\
\text { süreç olarak kodlanan } \\
\text { (ENCODED) }\end{array}$ & $\begin{array}{l}\text { iliş̧kiler ve rutinler } \\
\text { olarak gömülmüş olan } \\
\text { (ENCULTERED) }\end{array}$ \\
\hline & & Kodlanmış & Örtük \\
\hline & & \multicolumn{2}{|c|}{ FORMU } \\
\hline
\end{tabular}

Şekil I. Bilgi Türleri

\footnotetext{
3 Veri (Data), Malûmat (Information), Bilgi (Knowledge) kelimeleri Türkçe 'de sıklıkla birbirleri yerine kullanılan kelimelerdir. Veri (data), birbiri ile ilişkilendirilmemiș ham kayıtlardır. Malumat (information), işlenmiş veya anlam kazanmış verilerdir. Bilgi (knowledge) ise, değer kazanmış malumattır ve malumatın amaca yönelik olarak bir araya getirilmesidir (Myers, 1996). Yarı işlenmiş veriler, yani malumat insan beyninde sınıflandırılır, anlam kazandırılır ve problemleri çözmeye uygun bilgiye dönüştürülür. Bilgi malumata oranla ancak insan beyninde saklanır ve kişiden kişiye değişiklik göstere- 
Birinci tip bilgi kodlanmış (encoded) bilgidir. Bu tür bilgi işaret (yazılı) ve şekillere (görsellere) dökülmüş ulaşılması kolay ve transfer edilebilir diğer bilgiler ile bütünleşebilir bilgi türüdür. Bireyler ve kurumlar bu bilgiye ulaşabilir ve bilgiyi transfer edebilir ve saklayabilir. İkinci bilgi türü bireylerin sosyalle süreçleri ve kültürel paylaşımları ile anlayarak elde ettikleri kültürleşmiş (encultured) bilgidir. Toplumsal jest ve mimikler ve bunların kültürel olarak farklılaşması kültürleşmiş bilgiye örnektir. Diğer bir bilgi türü somutlaşmış (embodied) bilgidir. Bu bilgi türünde bilgi sosyal anlamda gözlemlenebilir. Bu bilgi türü kişinin içindedir ve toplumsal iletişim vasıtasıyla çevresini algılamak ve yorumlamak için kullandığı ilk bilgi türüdür. Zihinsel (embrained) bilgi ise kavramsal yetenekler ve bilişsel özellikler üzerine inşa edilmiştir. Formal, soyut ve teoriktir.

\section{Mesleki Bilginin Genleşmesi ve Uzmanlaşma ve Profesyonelleşme Tartışmaları}

Mesleki uzman bilgisi durağan değildir, icra koşullarının çeşitlenmesi ile beraber genişler. Bilgi alanındaki genişleme ihtiyacı mesleğin diğer mesleklere ait özel bilgi alanları ile temas kurması gerekliliğini ortaya çıkarır. Abbott (1988) mesleklerin Mesleki Sistem diye tanımladığı bağımsız bir sistem oluşturduklarını ve bu sistem içinde her birindeki değişikliklerin diğerlerini etkilediğini savunmaktadır. Ona göre değişimler dışsal ve içsel etmenlere bağlıdır. Dışsal değişiklikler mevcut veya yeni ortaya çıkmaya başlayan diğer meslek alanlarının mesleki icra için yeni yetki talebinden oluşurken içsel etmenler daha ziyade mesleğin kendi yetki alanına etki eden yeni bilgiden kaynaklanmaktadır. Benzer şekilde, DiMaggio (1989) mesleklerin ancak uygun nişler bulduğunda geliştiklerini, değişimin ise ancak yetki alanlarına karşı dışsal bir tehdittin varlığı neticesinde oluştuğunu belirtmektedir. Abbott'un öne çıkardığı yetki alanı belirli sınırlara sahiptir ve yetki alanları üzerindeki süregelen tartışmalar bilgi temeli üzerine inşa edilmiştir (Fitzgerald, 2016). Bir mesleğin karakterini belirleyen yetiler mesleğin sahip olduğu bilgi yığınından desteklenir (Greenwood, 1957). Mesleki bilgi yetki alanı üzerinde kontrol sağlamaya imkân veren ve mesleği uzman statüsüne taşıyan en önemli kaynaktır (Mclaughlinve Webster, 1998; Popovic, 2004).

Mesleki uzmanlık rutin uzmanlık ve adaptif uzmanlık olmak üzere iki çeşittir (Hatano ve Inagaki, 1986). Rutin uzmanlıkta meslek erbabı bariz bir hız ve doğruluk sergilerken usulün ötesine geçen yeni mesleki problemler karşısında uyum ve esneklik problemi yaşamaktadır (Hatano ve Oura, 2003). Buna karşın adaptif uzmanlıkların alan içindeki yeni problemlere karşı esneklikleri ve yaratıcılıkları daha da yüksektir (Hatano ve Oura, 2003). 
Schwartz, Bransford, ve Sears'a (2005) göre rutin uzmanlıktan uyarlanan uzmanlığa geçişte optimal uyumluluk koridoru oluşur (Şekil 2). Adaptif uzmanlıkta meslek sahibinin yaratıcılığı ve etkinliği yaratıcı problemlerin çözümünde müşterek şekilde artar. Bu artıştaki temel etmen ise yeni bilgi kazanımı ve bu bilginin mevcut bilgi ile yeni şekilde sentezlenme yetisidir. Lam (2002) tarafından tanımlanan bilgi türleri mesleki bilgi üzerinden incelendiğinde kodlanmış bilgi türlerinin transfer edilebilme özelliklerinden dolayı rutin uzmanlıkta, örtük bilgi türlerinin ise adaptif uzmanlıkta ön planda olduğu söylenebilir. Zira örtük bilgiler meslek sahibi tarafından kodlanmış bilgiler kullanılarak içsel olarak geliştirilir.

Abbott tarafından geliştirilen Mesleki Sistem özünde meslekleri yetki alanları üzerinden çatışmacı olarak tanımlamaktadır. Çatışma daha ziyade mesleğin kendine vazife addettiği yeni görevleri icrası sırasında kaçınılmaz olarak diğer meslekler ile temas etmeye başladığı sınırlarda meydana gelir. Bir mesleğin kendi dinamizmi nedeniyle oluşan bu durumda, meslek kendi amaçları dâhilinde diğer mesleklere ait yeni araştırma metotları, değişken, teori, kavram ve metotlara intiyaç duyar ve onları kademeli olarak içselleştirmeye başlar (Dogan, 1999). Her meslekte mevcut bilgi alanı sınırlarında mesleğini icra eden, bilgiyi takas eden ve hibrit alanlar yaratan öncü meslek sahipleri vardır (Dogan, 1999). Bu meslek sahipleri diğer alanlarla bilgiyi değiş tokuş ettiğinden adaptif uzmanlık karakteri sergilerler. Dolayısıyla uzmanlıktan kast edilen belirli özelleşmiş bir bilgi üzerinde hâkimiyet olup bu özel bilgi etrafında örgütlenme profesyonelleşmenin merkezinde yer almaktadır (Rothman ve Perrucci, 1971). Profesyonelleşme kavramı ise son yıllarca iyiden iyiye gündeme oturan, üzerinde farklı tartışmalar tesis edilen bir kavramdır. Genel itibari ile mesleki pratiğin kendine has bir yaşam tarzı oluşturduğu inancına dayanan bu kavram aslında her mesleğin amaçladığı bir hedef olarak görülmektedir. Profesyonelleşme tartışmaları incelendiğinde genel olarak teknik altyapıya sahip bir uzmanlık, dayanışmaya dayalı kurulmuş dernekler ve elde edilen toplumsal onay ve statü (Foote, 1953) neticesinde profesyonel mesleklerin uzmanlıkları sayesinde piyasayı kontrol edebilme, imkân olduğu takdirde tekel olma (Larson, 1977), devlet nezdinde özerklik (Birkett ve Evans, 2005) ve en nihayetinde özellikle maddi olmak üzere ödül kazanabilme vasfına kavuşacakları ön görülmektedir.

\section{Endüstriyel Tasarım Alanı ve Temel Bilgi Kümesi}

Şu ana kadar yürüttüğümüz tartışmalarda gerek meslek kavramının gerekse profesyonelleşmenin temelinde alana özel bilgi, bu bilginin korunması ve bilgi sayesinde elde edilmesi amaçlanan özerklik ve icra alanı dâhilindeki 
piyasayı kontrol etme hedefi ön plana çıkmış bulunmaktadır. Bu aşamadan itibaren tartışılması gereken alana özel bilginin nasıl ortaya çıktığı, niteliği, sınırları ve nasıl korunacağıdır. Başlı başına kapsama sahip bu tartışmayı yürütmek amacıyla konu endüstriyel tasarım alanı üzerinden ele alınacak, bu alana özel temel bilgi kümesine yoğunlaşacaktır.

Her profesyonel meslekte olduğu gibi endüstriyel tasarım alanı da belirli bir temel bilgi kümesi üzerin inşa olmuştur. Literatürde endüstriyel tasarım alanının temel bilgi kümesi üzeri üzerine tatminkar bir çalışmaya ulaşmak mümkün olmasa da ulaşılabilen en derli toplu kaynak Industrial Design Institute (Philadelphia) tarafından 2014 yılında yayımlanan "Industrial Design Body of Knowledge (IDBOK ${ }^{\text {TM }}$ Guide)" dır. Kitabın hazırlanmasında Amerika Birleşik Devletleri'nde bulunan 50 lisans program müfredatı incelemeye alınmış, tasarım profesyonelleri ve mühendislerden oluşan bir ekip katkıda bulunmuştur. Kitap tasarım alanına ait temel bilgi kümesini 12 adet temel bilgi alanı, 72 adet endüstriyel tasarım aksiyonu ve 44 adet tasarım süreç basamağı şekline ele almıştır. Kitabın temel yaklaşımı operasyonel olup 12 adet bilgi alanı altında sahip olunması gereken kavram, bilgi, süreç ve becerilerin listesi halindedir. Genel bir değerlendirme yapıldığında kitapta yer alan kavram, bilgi, süreç ve becerilerin listesi diğer disiplinlerde yer alan bilgi setleri ile örtüşmektedir. Kitabın söylemi daha ziyade bir tasarımcının "haberdar ve farkında olması gereken" kavramların listelenmesi şeklindedir. Bu listeleme endüstriyel tasarım mesleğini diğer alanlardan ayıracak sui generis bilgiyi tanımlamaktan yoksun gözükmektedir. Kaldı ki kitapta yer alan bilinmesi gereken yeterliliklerin çoğu, örneğin 3 boyutlu modelleme becerisi gibi uğraş seviyesindedir.

Peki, endüstriyel tasarım alanına ait, onu meslekstatüsüne taşıyan sui generis bilgi nedir? Bu soruyu cevaplayabilmek için evvela tasarım bilgisinin ne olduğu tartışımalıdır. Literatür incelendiğinde tasarım sürecinde kullanılan dört çeşit bilgiden bahsetmek mümkündür. Bunlardan ilki tasarımın yapılacağı tasarımı anlamlandırması beklenen özneye dönük bilgidir. İkinci bilgi tasarım yapmaya dair tasarımcının kendinde sahip olduğu bilgidir. Üçüncü bilgi tasarım nesnesinin sahip olduğu bilgidir. Dördüncü bilgi ise tasarım nesnesini anlamlandırması beklenen öznenin sahip olduğu tasarım bilgisidir. Sui generis bilgi açısından üzerinde özellikle durulması gereken bilgi türü tasarım yapmaya dair tasarımcının kendinde sahip olduğu bilgidir. Zira diğer bilgiler tasarımcının bu bilgisine destek veren ikincil bilgi türleridir.

Konu bilgi ve tasarımcı ilişkisi olduğunda tartışmanın ontolojik boyutları öne çıkmaktadır. Zira modern ontoloji varlık ve insan arasındaki etkileşimi bilgi üzerinden kurar. Ontoloji açısından varlık ve nesne ilişkisi iki boyut- 
ta ele alınır. Platon daha sonra Kant tarzı öznel idealizm açısından "tüm bildiklerimiz bilincimizin ürünüdürler" düsturu ile nesneye tali bir görev verilir ve bütün var olanlara ulaşmak için insandan yola çıkılmalıdır. Aristoteles tarzı nesnel idealizmde ise asıl gerçek varlık tek tek nesnelerdir ve bilgi ancak gerçek nesnelerin içerisinde saklıdır. Bu şu anlama gelmektedir. Varlık bilgi dışında geniş bir alan sahiptir ve bizim bilgi dediğimiz şey ancak varlığın ancak kısmi bir bölümünü nesneleştirir ve bilgi haline getiririz. Bu bağlamda tasarımcı kısıtlı şekilde sahip olduğu bilgiyi kullanarak ona kişisel tinini ve içinde bulunduğu zamana ait nesnel tini katarak bir nesneleştirme yaparak ürünü ortaya koyar. İşte tasarımcının sahip olduğu bilgi dediğimiz şey bu yaratım sürecinin bilgisidir. Tasarımcının ortaya koyduğu her ürünün fiziki real yapısı olduğu kadar, realitede görünüşe kavuşan bir irrealitesi vardır. Bu irrealite onu algılayan öznenin bilincinde yaşar. Bu irrealite üründeki tasarım düşüncesidir, tasarım düşüncesi fiziki realiteye katılan bir varlıktır. Tasarım düşüncesi realiteden pay alır ancak kendisi fiziki realitenin dışındadır ve fiziki realitede onun izlerini görürüz. Dolayısıyla her ürünün fiziki yapısı kadar bu fiziki yapı tarafından taşınan ve kullanıcıya aktarılmaya çalışılan bir tinsel katmanı vardır. Bu katman, yani tasarımcının kullanıcıya aktarmak istediği şey tasarım düşüncesidir. Eğer tasarımcının real objeye yaratım sürecinde kattığı tin kullanıc tarafından algılanıp bir karşılık buluyor ise tasarımcı ile kullanıcı arasında bir rezonans oluşur. $\mathrm{O}$ halde sui generis bilgi olarak aradığımız şey, diğer tüm bilgilerden beslenen, onunla bütünleşerek üründe vücut bulan ve kullanıcı ile etkileşime giren tinsel katman yani tasarım düşüncesi olmalıdır. Diğer tüm bilgiler ya tasarım düşüncesine altık sağlayan ya da düşüncenin fiziki hale gelmesini sağlayan bilgilerdir.

Tasarım düşüncesi, endüstriyel tasarım mesleğinin öz bilgisidir. Ezoterik ve kısmen örtüktür. Edinilmesi zor ve transferi kolay değildir. Bu bilgi zaman içinde şeklî eğitim ve mesleki tecrübe içinde şekillenir, diğer bilgiler vasıtası ile üst üste birikir. Tasarımcının ürününe kattığı tin bu düşüncenin dışa vurumu vücut bulmuş halidir. Tasarım düşüncesi içinde tasarımcının kişisel tinini barındırdığından bireyseldir, her tasarımcıda farklı şekilde ortaya çıkar. Tasarım düşüncesi aynı zamanda tasarımcının içinde bulunduğu zaman ve kültürü barındırdığı için, yani nesnel tin bileşeni bulunduğu için kolektiftir. Lam (2002) tarafından sınıflandıılan bilgi türlerini incelediğimizde, tasarım düşüncesi bir bilinç ürünü olarak deneyim, bilgi ve teknik ile somutlaşan ancak oluşurken diğer bilgileri de kullanan cisimleşmiş bilgi türüne denk gelmektedir. Bu bilgi türü bireysel ve örtük halde temel bilgi kümesinin özünü oluşturur. Tasarımcı bu örtük ve bireysel bilgisini ürün vasıtası ile kullanıcıya aktarmaya, bir bakıma ürün üzerinden mesajını iletmeye çalışır. Dolayısıyla tasarımın ürünü bir bilgi objesi haline gelerek içinde gömülü 
olan tasarım düşüncesini aktaran bir ortam haline gelir.

\section{Merkezi ve Mesleki Bilgi Olarak Tasarım Düşüncesi}

Meslekler doğası gereği farklı bilgi kaynaklarından beslenir ancak kendilerine has bilgiyi üreten, aktaran ve kollayan konumundadır. Peki, tasarım düşüncesi cisimleşmiş bir bilgi olarak endüstriyel tasarım mesleğinin profesyonelleşmesinde bir rolü olabilir mi? Bu bölümde profesyonel meslekler ve bilgi kavramlarının literatür üzerinden tanımlanmaya çalışılan genel özellikleri üzerinden konuyu tartışacağız.

Profesyonelleşme ve profesyonel bilginin ne olduğu konusunda literatürde farklı fikirler bulunmaktadır. Hughes'a (1963) göre, profesyonel meslekler insanların sorunlarına karşı ve onları çözmek niyetiyle, birkaç tür bilginin karışımı olan sistematik bilgi kullanır. Ona göre profesyonel meslekler uzun bir eğitim sonucu oluşan yüksek bilgi ve bu bilgi tekeli üzerine kurulmuştur. Bu onları özerk konuma taşır. Barber (1963) ise yeni ortaya çıkan mesleklere odaklanarak bu mesleklerin kendilerini topluma kabul ettirmek amacıyla var olan mesleklerin yetersizliklerini savunarak kendilerine bir konum elde etme mücadelesine girdiğini, örgütlenme çerçevesinde mesleki bilginin kullanım ve gelişmesine ilişkin yine kendilerinin geliştirdikleri bir otokontrole sahip olduklarını savunmaktadır. Her meslek profesyonelleşme idealine yaklaştıkça topluluk özelliği göstermeye çalışır ve bu öyle bir topluluktur ki birlikte hareket edilen alanlarda, meslekten olmayanların sadece kısmen anlayabilecekleri ortak bir dil ve hareket tarzı vardır (Goode, 1957). Diğer taraftan Haug (1972) bir profesyonelin tek başına bütün bilgileri öğrenmesinin imkânsız hale gelmesi ile beraber profesyonellerin bütün bilgileri edinmek yerine artık belli bir alanda uzmanlaşmaya başladıklarını savunarak bu durumun profesyonellerin toplumsal itibar ve güç hiyerarşisindeki konumlarını belirleyen bilgi tekeli kavramını tartışmaya açtığını savunmuştur. Oppenheimer (1972) ise bilginin tekelini ellerinde tuttuklarını iddia eden profesyonellerin giderek bürokratik ortamlarda çalışmaları ile beraber söz konusu "proleter bir biçimde" değişen koşullar neticesinde giderek proleterleştiklerini savunmaktadır.

Bu görüşler neticesinde öncelikli olarak tasarım mesleğinin merkezi bilgi unsuru olan tasarım düşüncesinin [1] sistematik bir bilgi olup olmadığını, [2] bu bilginin uzun bir eğitim ve deneyim üzerine kurulup kurulmadığını, [3] bu bilginin kullanım ve geliştirilmesine dönük mesleki bir özdenetimin olup olmadığını, [4] bu bilginin ezoterik doğası nedeniyle meslekten olmayanların sadece kısmen anlayabilecekleri ortak bir dil ve hareket tarzı yaratıp yaratmadığını ve nihayetinde [5] mesleğin bu bilgi üzerinde tekele sahip olup olmadığını tartışmamız gerekecektir. 
Sistematik bilginin temeli çeşitli konularda elde edilen bilginin kendi içinde mantıksal tutarlıı̆̆a sahip olacak şekilde bir sentez içinde birleştirmeye dayanır. Dolayısıyla tasarım düşüncesinin en azından bir tertibe yani düzene sokulmuş bir bilgi birikimi olması beklenir. Tasarım düşüncesinin sistematik olabilmesi için ise pratikte gözlemlenebilir bir rutinlikte icrasına bağlıdır. Konu gözlem olduğunda ise eğer bilgi barındırdığı örtük yapı nedeniyle ezoterik özellik gösteriyor ise gözlemde bilginin icrada kullanılışının metodolojik okunabilirliği ön plana çıkacaktır. Günümüzde ister kuramsal ister fiiliyata dökülmüş olsun birçok tasarım metodoloji önerisi bulunmaktadır. Bu metodolojilerin ortak noktası tasarım düşüncesinin sistematik bir akt olarak kullanılışı üzerine kuruludur ( Kelly, Littman ve Peters, 2001; de Mozota, 2003; Brown, 2009; Lockwood, 2009; Verganti, 2009; Rasmus, 2011). Bu akt ise belirgin bir prensip, tavır ve ruh halini barındırır. O halde tasarım düşüncesi örtüklüğünden bağısız bir şekilde sistematik olarak uygulanan bir tasarım bilgisidir. Tasarım düşüncelerindeki örtüklük ve heterojenlik farklı metotların önerilmesini sağlasa da aynı zamanda aynı sistematik içinde farklı zenginlikler de yaratmaktadır.

Her düşünce tarzında olduğu gibi tasarım düşüncesinin de gelişmesi süreç temellidir. Formel tasarım eğitiminin amacı bu gelişim sürecini oluşturmaktır. Tasarım literatüründe tasarım eğitime dönük birçok çalışmada tecrübesiz ve deneyimli tasarımcı adaylarının tasarım düşüncesini kullanma beceri ve seviyeleri konu edilmiştir (Ahmed, Wallace ve Blessing, 2003; Ahmed ve Wallace, 2004; Stones ve Cassidy 2007; Liikkanen ve Perttula, 2009, Özkan ve Doğan, 2013). Bu tür çalışmaların tümünde ampirik olarak tecrübesiz ve deneyimli tasarımcıların arasında tasarım düşüncesi açısından bilgi kaynaklarını kullanmada, süreci gerekçelendirmede, hedef ve sonuç ilişkisini kurgulamada farkların oluştuğu, deneyimin artması ile beraber daha etkin tasarım süreçlerinin ortaya çıktığı belirtilmektedir. Bu durum eğitim seviyesinin artması ile beraber tasarım düşüncesinin de geliştiğine işaret etmekte daha da ötesi tasarım düşüncesinin oluşumunun eğitim seviyesi ve deneyim ile ilişkisini tanımlamaktadır.

Eğer ortada mesleki bir bilgi var ise bu bilgi üzerinde özdenetimin olması kaçınılmazdır. Özdenetim örgütlü bir faaliyeti işaret etmekte ve üç asli öğeden oluşmaktadır: odaklanma (bir işe yoğunlaşıp, disiplinli bir şekilde çalışmak), odak dışındakileri engelleme (engelleyici kontrol), bilişsel esneklik (odak noktasını kontrollü olarak ve istendiği zaman değiştirebilmek). Endüstriyel tasarım alanına bakıldığında ister küresel ölçekte isterse yerelde farklı örgütlenme modelleri göze çarpmaktadır. Bu modellerin tasarım dü- 
şüncesi üzerindeki özdenetim daha ziyade mesleki eğitimin akreditasyonu, mesleki pratiğin tasnifi ve tanımlanması üzerine yoğunlaşmaktadır. Mesleki akreditasyon daha ziyade mesleki eğitimde standartlaşma, eş güdüm ve kalite hususlarına yoğunlaşırken, mesleki standartlaşma mesleğin başarı ile icra edilebilmesi için gerekli bilgi, beceri, tavır ve tutumların neler olduğunu gösteren asgari normların belirlenmesini amaçlar. Ancak elimizde hâlihazırda tasarım düşüncesinin ne olduğu, tasarım düşüncesi için gerekli bilgi, beceri, tavır ve tutumların neler olduğu, bunların nasıl korunduğu veya geliştirildiği konusunda belirleyici referans bir örgüt modeli veya dokümantasyon bulunmamaktadır. Daha evvelde bahsedildiği üzere "Industrial Design Body of Knowledge (IDBOK ${ }^{\text {TM }}$ Guide)" gibi çalışmalar özdenetimden öte temel bilgi alanının tasnifi niteliğindedir. Böyle bir eksiklik mesleki formel eğitimi almamış sıradan bireylerin fayda maksimizasyonu motivasyonu altında o alandaki özdenetim dönük boşluğunu ve ayrıca rantı fark edip, kendisini meslek erbabı olarak ilan etmesine kadar uzanan bir boşluk yaratmaktadır.

Mesleki bilginin bir özelliği, eğer ezotorik ise ancak o alandan gelenlerin anlayacağı, dışarıdakilerin ise ancak kısmen anlayabileceği bir dile ve hareket tarzına işaret etmesidir. Bu özellik bilginin kolektif özelliğinden kaynaklanır. Zira topluluk içinde zamanla oluşturulan bilgi topluluğun ortak birikimini de barındırır. Bu birikim kimi zaman jargon (özgü dil) kimi zaman ortak davranış kalıpları olarak kendisini gösterir. Jargonu oluşturan sözcükler o mesleğe ait olmayan bir kişi için anlaşılmaz gelebilir veya kimi yaygın sözcükler olmalarına rağmen tamamen farklı bir anlamda kullanılabilir. Ortak davranış modellerinin gözlemlenmesinde özellikle disiplinler arası tasarım takımları doyurucu bir içeriğe sahiptir. Zira farklı disiplinlerin bir araya geldiği bu takım kurgularında özellikle takımın oluşumu sırasında takım elemanları birbirlerini anlamak amacı ile yüksek işlem maliyetleri ödemekte takımlar gerçek amaçları dışında mesailerini birbirini anlama ve koordinasyona harcamaktadır (Katzenbach ve Smith, 1993). Disiplinler arası etkileşimlerde işlem maliyeti, ilk aşamada birbirini anlama, bilgi oluşturma, uzlaşma ve antlaşma süreçleri sonucunda harcanan emek ve zamandan oluşur. Eğer disiplinler kendilerine has örtük bilgi yüküne sahip ise maliyetler artar. Stempfle ve Badke-Schaub'a (2002) göre aynı disiplinden gelen elemanların oluşturduğu tasarım takımları dahi, takım çalışma sürelerinin 1/3'ünü takım oluşturma çabalarına ayırmaktadır. Sonnenwald'a (1996) göre ise deneyim ile beraber, takım elemanlarının hedef odaklı takım çalışmasına dönük strateji ve becerileri artmaktadır. Disiplinler arası tasarım takımlarına dönük ampirik çalışmalarda takım elemanlarının formasyon amacıyla ortaya çıkan işlem maliyetinin varlığı tasarım düşüncesi kavramının örtüklüğü, ve farklı disiplinlerin bu örtüklüğü 
aşma çabalarından kaynaklanmaktadır.

$\mathrm{Bu}$ genel değerlendirmeler neticesinde endüstriyel tasarım alanı tasarım düşüncesi bilgisi üzerinde tekele sahip midir? Tasarım düşüncesinin yapısı nedeniyle tekel için gerekli koşulların büyük bir bölümü sağlanmış olsa da bu bilginin kullanım ve geliştirilmesine dönük mesleki bir özdenetimin olmaması tekel olma düşüncesini zayıflatmaktadır. Kaldı ki tekel olmak farklı biçimlerde olabilir. Illk tekel biçimi doğal tekeldir ki bu koşulda tasarım düşüncesi bilgisinin mahiyeti, sahipliği ve icrası konusunda disiplinler arasında bir rekabet olmaması beklenir. Farklı disiplinlerin tasarım düşüncesi bilgisini sahiplenmesi ve kullanması konusunda bir kısıt olmaması doğal tekel savını çürütmektedir. İkinci tekel türü yasal tekel olup, kanunun tespit ettiği şartlar bilgi ve icrası üzerinde tekel durumunu yaratmaktadır. Örneğin tıp, hukuk ve mimarlık gibi alanlar kendi öz bilgileri üzerine yasal tekel imkânına sahiptir. Bu koşulda endüstriyel tasarım alanı için geçerli değildir. Üçüncü tür tekel durumu akdi tekel olup bu koşulda disiplinler kendi aralarındaki rekabeti azaltmak amacıyla aynı temel bilgi kümesi üzerinde birden fazla uzmanlaşmaya ayrılarak anlaşırlar. Bu antlaşma süreci kimi zaman özellikle egemenlik alanı üzerine sancılı (mimarlık-şehir planlama; mimarlık-iç mimarlık alanları gibi) kimi zaman tasarrufa dayalı uzlaşmacı olsa da (mühendislik alt alanları gibi) Abbott tarzı uzun yıllara dayalı bir mücadeleye dayanır. Zannımızca akit koşullarının oluşabilmesi için iki farklı tekel koşulunun bağımsız bir şekilde o disiplin tarafından yaratılması gerekmektedir. Bu koşullar fiili tekel ve psikolojik ve sübjektif tekeldir. Çalışmamızın sonuç kısmında bu tekeller tartışmaya açılarak endüstriyel tasarım alanının kendi öz bilgisi olan tasarım düşüncesi üzerindeki tekel olabilme olanakları tartışmaya açılacaktır.

\section{Sonuç}

Bir disiplinin kendi bilgi alanı üzerindeki hâkimiyeti oluşturması ve bunu diğer disiplinlere kabul ettirebilmesi için fiili tekel ve psikolojik ve sübjektif tekel koşullarını sağlaması zaruridir. Fiili tekelden kastettiğimiz şey bir grup tarafından meslek alanının sahiplenilerek icranın eyleme dökülmüş halidir. Bu de facto durum aynı alana ilgi duyan meslekler arasında mesleki sürtüşmeler veya çıkar çatışmalar yaratsa da kendisine bir mevki, bir yer edinmek amacında olan meslekler için çatışma tarihsel olduğu kadar kaçınılmaz ve mücadele açsından yaşanılması gereken bir durumdur. Meslek alanlarının genleşmesi ile beraber fiili tekel durumlarında çatışma bir grubun diğer gruba karşı çıkmasını ve bir grubun amaçlarına ulaşmak için öbür grubun engellemelerine karşı önlem alması nedeniyle sıklıkla karşılaşılan ancak yönetilmesi gereken bir süreçtir. Meslekler arası çatışmalar genelde 
bir iş bölümü problemi olup, uzmanlaşmaların, farklılaşmaların ve yeni uzmanlıkların ortaya çıkması, bunların da kendilerine uygun değer yargıları ve normları oluşturması, daha da ötesi iş piyasasındaki kıt kaynakların bölüşümü ile alakalıdır. Çatışmanın büyüklüğü ne olursa olsun, hem fiili durumu yaratan grubun içinde hem de fiili durumdan rahatsı olan diğer meslek grupları ile olumlu ve işbirlikçi bir kültür kurmak çatışmaya konu olan tarafların olayları ve durumu algılama tarzlarını anlamak ve bu yolla çatışmayı yönetmek için önemlidir. Fiili tekel hevesinde olan ve çatışmaya maruz kalan meslek gruplarının çatışmayı yönetmek, çatışmaya taraf olanların zararını asgariye düşürmek için belirli stratejilere sahip olmaları gereklidir. Bu stratejilerden ilki örgütlülüktür. Örgütlenmede asıl olan örgütü oluşturan bileşenler arasında kurulan tanımlı bir ilişki ve iletişimdir. Fiili tekel amacında olan meslek erbabı açısından örgütlenmenin ilk önemi çatışmaya zemin oluşturacak amaç birlikteliği oluşturmaktır. Paradoksal olarak her örgüt kendi içinde çatışmaya gebe olsa da örgütlü mücadele için muhatap olunacak kütlenin varlığı önemlidir. Mesleki örgütlenmenin çatışma açısından diğer bir önemi çatışmayı yönetme aşamasında ihtiyaç duyulacak argüman zenginliğini yaratmaktır. Bu argümanlar temel olarak uzmanlaşma ve farklılığı ortaya koymak, uygun değer yargıları, norm ve standartları oluşturmak, mesleği tanıtmak, meslek alanını ilgilendiren konularda toplumu bilgilendirmek, meslek alanındaki gelişmeleri izlemek ve yaymak, mesleğin gelişimine katkıda bulunacak her türlü etkinliği düzenlemek ve desteklemek, her türlü bilimsel ve mesleki yayınlar yapmak meslek mensuplarının haklarını korumak gibi hususları kapsamaktadır. Dolayısıyla argüman üretmekten kastımız kısaca mesleki temel bilgi kümesinin oluşturulması ve bunun üzerindeki hakimiyetin tesisidir. Fiili tekelin varlığı ancak ikna edici mesleki argümanların mevcudiyeti ve bu argümanlar ile tutarlı bir icradan oluşur. Konu ikna etmek olduğunda çatışmayı yönetmek açısından rekabete (kayıp-kayıp; kazan-kayıp) ve işbirliğine dayalı (kazan-kazan) iki stratejiden bahsetmek mümkündür. Friedson'a (1970) göre meslekler güç ilişkisi açısından argümanları ile hem toplumu hem de diğer meslekleri ikna etmek zorundadır. Mesleklerin diğer meslekleri ikna süreci daha ziyade rekabete dayalı iken toplumsal ikna eğer o meslek alanı toplumsal işbirliği açısından taraflara değer üretmeye başlıyorsa işbirliğine dayalıdır. Konu toplum olduğunda psikolojik ve sübjektif tekel koşullarını sağlaması o meslek için önem kazanmaktadır. Mesleklerin toplumsal itibar ve güç hiyerarşisindeki konumunu belirleyen toplumsal kabuldür. Toplumsal bir fayda üreten, kamu çıkarı esası üzerinden toplumsal çıkarı kendi çıkarlarından önde gören meslekler toplumsal kabul ve akabinde psikolojik ve sübjektif tekel koşullarını sağlamaya başlamış demektir. Psikolojik ve sübjektif tekel koşulları öncelikle sağlıklı argümanların yaratılması, bu argümanların 
icraya yansıması ve denetlenmesi daha sonra ikna edici iletişim faaliyetleri ile hedef kitleye iletinin ulaştırılmasında oluşur. Toplumda psikolojik ve sübjektif tekel koşullarını oluşturan ve toplumsal kabul ile toplum desteğini alan meslekler diğer meslekler ile girdikleri rekabetçi çatışmada büyük bir avantaj sağlarlar. Bu avantajlar toplumsal desteği kaybetmek istemeyen diğer meslek gruplarını işbirliğine zorlar.

Endüstriyel tasarım alanı özelinde düşünüldüğünde, suigeneris bilgi olan tasarım düşüncesi üzerinde mesleğin tekel olmadığı aşikardır. Bu nedenle öncelikle yapılması gereken de facto icranın mesleki argümanlar ile desteklenmesidir. Argümanlar temel bilgi kümesi olduğundan örgütlü olarak temel bilgi kümesinin meslek erbabı tarafından yaratılması, icraya yansıması ve denetlenmesi ve bu argümanların kamuya sunularak tartışma zemini oluşturulması şarttır. Böylelikle de facto durumun de jure, yani hukuken tanınan olguya dönüşmesi için ilk adım atılmış olacaktır. 


\section{Kaynakça}

Abbott, A. (1988). The System of Professions. Chicago: University of Chicago Press.

Abbott, A. (199I). "The Future of Professions: Occupation and Expertise in the Age of Organization”, Research in theSociology of Organizations, 8(I), I7-42.

Ahmed, S., Wallace, K. M., ve Blessing, L. T. (2003). "Understanding the Differences Between How Novice and Experienced Designers Approach Design Tasks". Research in Engineering Design, I4(I), I-II.

Ahmed, S., ve Wallace, K. M. (2004). "Understanding the Knowledge Needs of Novice Designers in the Aerospace Industry”. Design Studies, 25(2), I55-I 73.

Barber, B. (1963). "Some Problems in the Sociology of the Professions", Daedalus, 92(4), 669-688.

Birkett, W.P. ve Evans, E. (2005). "Theorising Professionalisation: A Model for Organising and Understanding Histories of the Professionalising Activities of Occupational Associations of Accountants", Accounting History, 10(I), 99-127.

Blackler, F. (1995). “Knowledge, Knowledge Work and Organizations: An Overview and Interpretation”, OrganizationStudies, I6(6), 102I-1046.

Brante, T. (20II). "Professions as Science-Based Occupations", Professions and Professionalism, I(I), 4-22. Brown, T. (2009). Change by Design: How Design Thinking Transforms Organizations and Inspires Innovation. New York: Harper Collins Publising.

de Mozota, B.B. (2003). Design Management: Using Design to Build Brand Value and Corporate Innovation. New York: Allworth Press.

DiMaggio, P. (1989). "Review of the Book The System of Professions, by A. Abbott", American Journal of Sociology 95(2), 534-535

Dogan, M. (1999). Marginality. M. A. Runco ve S. R. Pritzker (Editörler). Encyclopedia of Creativity. Kaliforniya: Academic Press. s. I79- 183.

Evetts, J. (20I3). “Professionalism: Value and Ideology”, Current Sociology, 6I (5-6), 778796.

Fitzgerald, L. (2016). Interprofessional Interactionsand Their Impact on Professional Boundaries. E. Ferlie, K. Montgomery ve A.R. Pedersen (Editörler). The Oxford Handbook of HealthCare Management. Oxford: Oxford University Press. s. I88-209. 
Freidson, E. (1970). Professional Dominance. Şikago: Atherton.

Foote, NN. (1953). "The Professionalization of Labor in Detroit", Americanjournal of Sociology, 58(4), 37I-372.

Gispen, K. (1989). New Profession, Old Order: Engineers and German Society, I8I5-1914. Cambridge: Cambridge University Press.

Gorman, E. H. ve Sandefur, R. L. (20II). "Golden Age Quiescence and Revival: How the Sociology of Professions Become the Study of Knowledge-Based Work" Work and Occupations, 38(3), 275-302.

Goode, W. (1957). "Community Within a Community: The Professions" Americani Sociological Review, 22, 194-200.

Govier, T. (1997). Social Trust and Human Communities. Montreal: McGill-Queen's University Press.

Greenwood, E. (1957). “Attributes of a Profession”, Social Work, 2, 45-55.

Hatano, G. ve Inagaki, K. (1986). Two Courses of Expertise. H. Stevenson, H. Azuma ve K. Hakuta (Editörler). Child Development and Education in Japan. New York: Freeman. s. 262-272.

Hatano, G. ve Oura, Y. (2003). "Commentary: Reconceptualizing School Learning Using Insight from Expertise Research”,Educational Researcher, 32(8), 26-29.

Haug, M. (1972). "Deprofessionalization: An Alternate Hypothesis for the Future”, Sociological Review, 20(I), 195-2II.

Hughes, E. (1963). “Professions”, Daedalus, 92(4), 655-668.

Katzenbach, J. R., ve Smith, D. K. (1993). The Wisdom of Teams: Creating The HighPerformance Organization. Boston: Harvard Business Press.

Kelly, T., Littman, J. ve Peters, T. (200I). The Art of Innovation: Lessons in Creativity from IDEO, America's Leading Design Firm. New York: Doubleday.

Kuhlmann, E. (2006). "Traces of Doubt and Sources of Trust: Health Professions in an Uncertain Society”, Current Sociology, 54(4), 607-620.

Lam, A. (2002). "Tacit Knowledge, Organiztional Learning and Societal Institutions: An Integrated Framework”, Organizational Studies, 2 I (3), 487-5I3.

Larson, MS. (1977). The Rise of Professionalism: A Sociological Analysis, California: University of California Press. 
Liikkanen, L. A., ve Perttula, M. (2009). "Exploring Problem Decomposition in Conceptual Design Among Novice Designers”. Design Studies, 30(I), 38-59.

Lockwood, T. (2009). Design Thinking: Integrating Innovation, Customer Experience, and Brand Value. New York: Design Management Institute.

Mclaughlin, J. ve Webster, A. (1998). "Rationalising Knowledge: IT Systems, Professional Identities and Power”, The Sociological Review, 46(4), 78I-802.

Merton, R. K. (1968). Social Theory and Social Structure. New York: The Free Press.

Morris, T.ve Empson, L. (1998). “Organisation and Expertise: An Exploration of Knowledge Bases and the Management of Accounting and Consulting Firms", Accounting, Organizations and Society, 23(5-6), 609-624.

Myers, P. (1996). Knowledge Management and Organizational Design. Boston: Butterworth\&Heinemann.

Oppenheimer, M. (1972). "Proletarianization of the Professional", Sociological Review, 20(I), 2I3-227.

Özkan, O., ve Doğan, F. (2013). "Cognitive Strategies of Analogical Reasoning in Design: Differences Between Expert and Novice Designers”. Design Studies, 34(2), I6I- 192.

Parsons, T. (1954). Essays in Sociological Theory. Glencoe: Free Press.

Parsons, T. (2005). The Social System. Oxon: Taylor \& Francis Group.

Polyani, M. (2009). The Tacit Dimension. Chicago: The University of Chicago Press.

Popovic, V. (2004). "Expertise Development in Product Design-Strategic and DomainSpecific Knowledge Connections” Design Studies, 25(5), 527-545.

Rasmus, D.W. (20I I). Management by Design: Applying Design Principles to the Work Experience. New Jersey: John Wiley\&SonsCo.

Ritzer, G. (1975). "Professionalization, Bureaucratization and Rationalization: The Views of Max Weber”, Social Forces, 53 (4), 627-634.

Rothman, R.A. ve Perrucci, R. (197I). "Vulnerability to Knowledge Obsolescence Among Professionals”, Sociological Quarterly, 12 (2), I47-I58.

Schwartz, D. L.,Bransford, J. D., ve Sears, D. (2005). Efficiency and Innovation in Transfer. J. Mestre (Editör). Transfer of Learning from a Modern Multidisciplinary Perspective. NC: Information Age Publishing. s. I-5I.

Sonnenwald, D. H. (1996). "Communication Roles That Support Collaboration During the 
Design Process”. Design Studies, I7(3), 277-30I.

Stempfle, J., ve Badke-Schaub, P. (2002). "Thinking in Design Teams-An Analysis of Team Communication”. Design Studies, 23(5), 473-496.

Stones, C., ve Cassidy, T. (2007). "Comparing Synthesis Strategies of Novice Graphic Designers Using Digital and Traditional Design Tools”. Design Studies, 28(I), 59-72.

Svensson, L.G. (2006). “New Professionalism, Trust and Competence”, Current Sociology, 54(4), 579-593.

Young, M. ve Muller, J. (20/4). Introduction and Framing the Issues. M. Young, ve J. Muller. (Editörler). Knowledge, Expertise and Professions. Oxon: Routledge s.3-I 7.

Verganti, R. (2009). Design Driven Innovation. Massachusetts: Harvard Business School Publishing. 